\title{
The nuance of meaning and kind of synonymy sensory response adjective in Indonesian
}

\author{
Nila Oktami ${ }^{1}$, Ngusman Abdul Manaf ${ }^{2}$, Novia Juita ${ }^{3}$ \\ ${ }^{123}$ Universitas Negeri Padang, Padang - Indonesia, (nilaoktami57@gmail.com)
}

\begin{abstract}
Absolute synonymy never encountered in any language. The near synonyms still have different meanings, though only in nuances. If there is no difference in nuance between the pairs of synonyms then one of the words will disappear from the vocabulary. This study aims to explain the nuances of meaning and kind of pair synonym sensory response in Indonesian adjektive. This research is a qualitative descriptive method. The results showed that: (1) not all sensory responses Indonesian adjectives have a pairs synonym; (2) there are different nuance of meaning in every pair of synonymous sensory response adjektive; and (3) only two kind of synonymy in pairs synonymous sensory response adjectives was found, they are complete and absolute, and incomplete and not absolute. Synonyms word can concretize the use a personal language, so that trought language the communication is clear interesting. Paying attention to nuances of meaning that is synonymous Indonesian adjectives in speaking and writing can add color, sharpness, and precision of the wording.
\end{abstract}

Keywords: adjectives sensory feedback, shades of meaning, and the type of synonymy.

This is an open access article distributed under the Creative Commons 4.0 Attribution License, which permits unrestricted use, distribution, and reproduction in any medium, provided the original work is properly cited. (O2018 by author and Faculty of education, Universitas Negeri Padang.

\section{Introduction}

Synonym problem has attracted the attention of researchers language. Research on synonyms has been carried out by researchers at local, national, regional, and international, which is carried out by (1) Taylor (2002) near synonym as co-extensive the categories: 'hight' and 'tall' recivited; (2) Edmonds \& Hirts (2002) examined near synonymy and lexical choise; (3) Webb (2007), examined the influence of synonyms for learning a second language vocabulary; (4) Ekoyanantiasih \& Winarti (2010) the relationship of meaning synonymy in Indonesian human nouns; (5) Utami (2010) the noun in Indonesian synonyms; (6) Wahyuningsih (2013) the human noun synonymy in Malay dialect Sambas; (7) Dangli (2014) unit of synonymy and lexical relations; (8) Danglli \& Abazaj (2014) lexical cohesion, word choice, and synonymy in academic writing; (9) Carapic (2014) near synonymy analysis of descriptive adjectives; (10) Junianto (2015) nuance meaning of the verb feel of hand activity in Indonesian; and (11) Rahmati (2015) semantics division that includes homonyms, synonyms, and antonyms.

Synonym has been considered important in the last two decades as one of the most affecting linguistic phenomenon lexicon structure. However, not much attention is given to this idea about the field of lexicography, psychology, or even linguistic (Edmonds and Hirst, 2002, p. 115). One of the 
least understood in semantic relationships are synonyms (Taylor, 2002, p. 265; Laufer, 1990). The word can be described as a pair of synonyms is words that are interchangeable in any context without changing the meaning of the cognitive and emotive meaning of the word (Jakimovska, 2013, p. 10).

Absolute synonymy never encountered (Bloomfield, 1993; Cruse 2000). Although the words are synonyms have the same meaning, but the meaning is not comprehensive. Cruse (2000) says that"natural languages abhor absolute synonyms just as nature abhors a vacuum."That is, "bahasa alam membenci sinonim mutlak seperti alam membenci kekosongan." The word is synonymous close it actually still has a different meaning, although the difference is only in nuance of meaning (Veerhar, 1999; Edmonds and Hirst, 2002, p. 115; Pateda, 2010). If there are no nuance of difference again between pairs of words are synonyms, then one will be missing from the vocabulary, and said the other live. Thus, even though the words are synonyms have the same meaning, that meaning is not entirely the same.

Finding the right words to use in any given situation should be careful and need to consider the differences between all the options. The correct use of synonyms with the writing process can add color and accuracy to the text (Danglli \& Abazaj, 2014, p. 628). The results of analyzing the words for the synonym pair will help speakers in using words that are synonyms partner appropriately. According to Laufer (1990), very little research into the effects of synonyms for learning vocabulary and synonym has been listed as one of several factors that can make the words more difficult to learn. Learning vocabulary with synonyms will be easier than learning words without recognizing synonyms (Webb, 2007, p. 121).

The words have synonyms relationships include various classes of words. Adjectives are part of a class of words that has its own peculiarities. Wetzer (1996) suggested that the adjective can function as a 'umbrella' to express a number of concepts related to the ownership and specificity in its status as a category of words. In cross-language, adjectives easily recognized as a category of the lexicon because of only adjektive the only category of words that can contain certain specific semantic meaning and are not owned by the category of other words that are easily recognizable (Umiyati, 2015, p. 61). One kind of adjective most used in everyday life is a sensory response adjective, such as sight, hearing, smell, touch, and taste (Alwi, H., Dardjowidjojo, S., Lapoliwa, H. \& Moeliono, AM, 2003). Sensory response adjectives have many pairs synonyms use should be considered in the use of language. Although adjective tasty and delicious synonymous, but the use of enak and lezat (tasty and delicious) are not interchangeable in any context: (1) Pada hari ini kondisi badan saya kurang enak.On this day I am less body good condition. (2) *Pada hari ini kondisi badan saya kurang lezat.* On this day my body condition is less tasty.

Both couples are synonymous words, but the meaning of the two are not exactly the same. Enak shows the meaning of 'taste of the food or beverage appetizing perceived by the tongue; the atmosphere is cozy and the atmosphere pleasant body or mind ', but lezat just shows the meaning of' taste of the food or beverage appetizing perceived by the tongue. A tasty appropriate adjective used in the context of the sentence (1), but not exactly when used in the context of sentence (2).

Based on the previous description, it is known that research on synonyms is often made. Assessment synonym conducted by previous researchers only discusses the meaning of the same elements, but less examine aspects of shades of meaning in the pair of synonyms. Meanwhile, the class studied the synonymous word generally only on the verb and noun. Past research has yet to explain thoroughly the adjective synonymous. This study is aim to determine (1) pair adjective synonymous sensory response in Indonesian; (2) kind of synonymy adjective pairs sensory response in Indonesian; and (3) nuance of meaning adjective pairs sensory response in Indonesian. This study provides information on the meaning of smooth and sharp in pairs synonymous adjectives nuance 
sensory response of meaning so that the user can select the language and use the language correctly.

\section{Method}

The research is qualitative research using a descriptive method. In this study, used the techniques of content analysis to explore the contents of the research data and give meaning to the interpretation of the data. This research data is basic sensory response adjectives Indonesian synonyms used in a variety of orals and written standards in formal situation and informal situations. The code source for this research is Padang Ekspres newspaper, Kompas Online, Talkshow Mata Najwa, Kick Andy, and Doctor OZ Indonesia. Collection technique code used is the recording of documents, tapping, introspection. The technique of code analyzing used in the study was classified into three stages according to the research objectives. First, make clear a couple adjective synonymous sensory response in Indonesian by three test methods synonymies, namely the analysis of components of meaning, antonyms, and substituted. Second, explain the type of adjective synonymous synonymy pairs in Indonesian. To test this type of synonymy can also be based on an analysis of components of meaning. Synonymy there are four types, namely the complete and absolute synonyms, complete and absolute, complete and absolute, and incomplete and not absolute. Third, explaining the nuances of meaning is synonymous sensory response Indonesian adjectives.

\section{Results and Discussion}

After analyzing the data for 80 pairs of adjectives sensory response that allegedly synonymous, only 60 pairs were proved synonymous. The following are the types of synonymy and shades into meaning 60 pairs of adjectives sensory response of the Indonesian synonymous.

Table 1. Kind of Synonymy and Nuance of Meaning Sensory Response Indonesian Adjective

\begin{tabular}{|c|c|c|c|c|c|c|}
\hline \multirow{3}{*}{ No. } & \multicolumn{2}{|c|}{ Pair Synonyms } & \multirow{3}{*}{$\begin{array}{l}\text { Sensory } \\
\text { Rensponse }\end{array}$} & \multirow{3}{*}{ Synonym type } & \multicolumn{2}{|c|}{ Nuance Meaning } \\
\hline & $\mathbf{A}$ & B & & & Nuance & INM (\%) \\
\hline & & & & & Meaning & \\
\hline 1. & lancar & fasih & Hearing & incomplete and not absolute & enough & 33 \\
\hline 2. & buruk & jelek & Sight & incomplete and not absolute & strong & 45 \\
\hline 3. & enak & lezat & Foretaste & incomplete and not absolute & strong & 44 \\
\hline 4. & enak & nikmat & Foretaste & incomplete and not absolute & enough & 33 \\
\hline 5. & enak & sedap & Foretaste & incomplete and not absolute & enough & 33 \\
\hline 6. & lezat & nikmat & Foretaste & incomplete and not absolute & strong & 38 \\
\hline 7. & lezat & sedap & Foretaste & incomplete and not absolute & strong & 38 \\
\hline 8. & nikmat & sedap & Foretaste & incomplete and not absolute & strong & 36 \\
\hline 9. & heboh & geger & Hearing & incomplete and not absolute & enough & 33 \\
\hline 10. & heboh & ribut & Hearing & incomplete and not absolute & enough & 33 \\
\hline 11. & heboh & gaduh & Hearing & incomplete and not absolute & enough & 25 \\
\hline 12. & heboh & ricuh & Hearing & incomplete and not absolute & enough & 33 \\
\hline 13. & heboh & ingar & Hearing & incomplete and not absolute & enough & 33 \\
\hline 14. & geger & ribut & Hearing & incomplete and not absolute & strong & 50 \\
\hline 15. & geger & gaduh & Hearing & incomplete and not absolute & quite & 25 \\
\hline 16. & geger & ricuh & Hearing & incomplete and not absolute & enough & 33 \\
\hline 17. & geger & ingar & Hearing & incomplete and not absolute & enough & 33 \\
\hline 18. & ribut & gaduh & Hearing & incomplete and not absolute & strong & 43 \\
\hline 19. & ribut & ricuh & Auditory & incomplete and not absolute & enough & 22 \\
\hline 20. & ribut & ingar & Hearing & incomplete and not absolute & quite & 33 \\
\hline 21. & gaduh & ricuh & Hearing & incomplete and not absolute & weak & 14 \\
\hline 22. & gaduh & ingar & Hearing & incomplete and not absolute & strong & 50 \\
\hline 23. & ricuh & ingar & Hearing & incomplete and not absolute & strong & 50 \\
\hline 24. & cantik & asri & Sight & incomplete and not absolute & strong & 50 \\
\hline 25. & cantik & elok & Sight & incomplete and not absolute & quite & 33 \\
\hline 26. & cantik & indah & Sight & incomplete and not absolute & enough & 25 \\
\hline
\end{tabular}




\begin{tabular}{|c|c|c|c|c|c|c|}
\hline 27. & cantik & ayu & Sight & incomplete and not absolute & weak & 17 \\
\hline 28. & asri & indah & Sight & complete and not absolute & no nuanced & 0 \\
\hline 29. & asri & ayu & Sight & incomplete and not absolute & strong & 40 \\
\hline 30. & elok & manis & Vision & incomplete and not absolute & strong & 38 \\
\hline 31. & elok & indah & Vision & incomplete and not absolute & strong & 40 \\
\hline 32. & elok & ayu & Vision & incomplete and not absolute & weak & 14 \\
\hline 33. & manis & ayu & Eyesight & incomplete and not absolute & strong & 38 \\
\hline 34. & indah & ayu & Vision & incomplete and not absolute & tbn & 0 \\
\hline 35. & kecil & $\operatorname{mini}$ & Sight & incomplete and not absolute & strong & 43 \\
\hline 36. & $\operatorname{mini}$ & mungil & Vision & incomplete and not absolute & strong & 43 \\
\hline 37. & terang & cerah & Vision & incomplete and not absolute & strong & 50 \\
\hline 38. & dingin & sejuk & Palpability & incomplete and not absolute & strong & 50 \\
\hline 39. & tawar & hambar & Foretaste & incomplete and not absolute & enough & 36 \\
\hline 40. & nyaring & lantang & Hearing & incomplete and not absolute & strong & 40 \\
\hline 41. & apik & rapi & Vision & incomplete and not absolute & weak & 17 \\
\hline 42. & ngilu & nyeri & Palpability & incomplete and not absolute & strong & 40 \\
\hline 43. & kotor & jorok & Vision & incomplete and not absolute & enough & 33 \\
\hline 44. & kotor & kumuh & Vision & incomplete and not absolute & enough & 33 \\
\hline 45. & jorok & kumuh & of vision & incomplete and not absolute & strong & 40 \\
\hline 46. & harum & wangi & Smell & incomplete and not absolute & enough & 25 \\
\hline 47. & harum & sedap & Smell & incomplete andabsolute & strong & 50 \\
\hline 48. & wangi & sedap & of smell & incomplete and not absolute & strong & 40 \\
\hline 49. & gemuk & gendut & Vision & incomplete and not absolute & strong & 43 \\
\hline 50. & kurus & langsing & Vision & incomplete and not absolute & strong & 50 \\
\hline 51. & langsing & ramping & Vision & incomplete and not absolute & enough & 25 \\
\hline 52. & jernih & bening & Vision & incomplete and not absolute & strong & 50 \\
\hline 53. & benjol & bengkak & Vision & incomplete and not absolute & strong & 50 \\
\hline 54. & keren & gagah & Vision & incomplete and not absolute & strong & 50 \\
\hline 55. & keren & tampan & Sight & incomplete and not absolute & enough & 29 \\
\hline 56. & keren & ganteng & Vision & incomplete and not absolute & enough & 33 \\
\hline 57. & gagah & tampan & Sight & incomplete and not absolute & enough & 33 \\
\hline 58. & gagah & ganteng & Sight & incomplete and not absolute & strong & 40 \\
\hline 59. & tampan & ganteng & Vision & incomplete and not absolute & enough & 25 \\
\hline 60. & pahit & getir & Teste & incomplete and not absolute & quite & 25 \\
\hline
\end{tabular}

1. Pairs sensory response adjective synonyms in Indonesian

Not all pairs of words that are considered synonymous proven synonymous. For testing, synonymous adjectives pair allegedly synonymous takes as a discussion adjective is cantik and elok. meaning component test

Table 2. Component Analysis Adjective meaning beautiful and elegant

\begin{tabular}{cllcc}
\hline & & \multicolumn{2}{c}{ Mair Synonymous } \\
No. & & \multicolumn{2}{c}{ Meaning component } & cantik \\
1. & Cogniti- & beautiful on the face or the face of woman & + \\
& ve & a beautiful in the form and artificial & + & + \\
& & beautiful(story shirt, and such) & + & + \\
& & good heart & + & + \\
2. & Emotive & has a delicate flavor value & - & + \\
\hline
\end{tabular}

To analyze the meaning synonymy with the component analysis is used spanning the meaning of intensity equation by using the scale obtained by dividing the number of components of meaning along with the number of components compared with the following steps.

$$
\text { IPM }=\frac{\text { number of components of the same meaning }}{\text { the number of components of the meaning being compared }} \times 100
$$

$\mathrm{IPM}=<50 \% \quad$ not synonymous 


$$
\begin{aligned}
& \mathrm{IPM}=50 \%-66 \% \quad=\text { low } \\
& \mathrm{IPM}=67 \%-83 \% \quad=\text { medium } \\
& \mathrm{IPM}=84 \%-100 \% \quad \text { =strong, }
\end{aligned}
$$

Be based on table 2, pair adjectives couple cantik and elok has four components common meaning of the six components of meaning are comparable. So cantik and elok to look for the intensity of its meaning following equation.

$$
\begin{aligned}
\text { INM } & =\frac{4}{6} \times 100 \% \\
& =67 \%
\end{aligned}
$$

Based on the equation significance test, it can be stated that a couple adjectives cantik and elok synonymous for the word pair has in common elements of meaning more than $50 \%$ are in the moderate range.

\section{antonyms test (antagonism)}

The word can be contrasted with a number of other words. Couple words can be said to be synonymous if the pair is said to have an antonym or opposition said the same. Conflicts can result in synonyms (Ullman, 2007: 143-145). After testing components of meaning to the adjective cantik and elok antonyms test is then performed to test whether these adjectives have the same antonyms.adjectives Cantik and elok contradictory with the word meaning buruk or jelek.Based on the antonym test the adjective cantik and elok synonymous. Not all adjectives, synonyms have the same antonyms. In this study, there was found adjective synonymous because it has the same meaning elements but do not have the same antonyms. For example, adjectives hambar and tawar. Based on the foregoing, it can be concluded that the antonym test cannot be said as an essential condition for testing synonyms for words that is considered synonymous. The most influential test determines the pair of words is synonyms meaning component test and test to sustitute.

\section{substitution test}

Substitution tested is a decisive test for determining the synonymous word pairs or not. How the test is synonymous with the substitution has been described Lyons (1977) and Ullman (1973). If a word can be replaced with other words in the same sentence context and meaning of that context has not changed, it can be said the two words are synonymous. Lyons further argued if the two sentences have the same structure, the same meaning, and only different because in one sentence that includes the wordy, then $\mathrm{x}$ is synonymous with $\mathrm{y}$. Here is a test for adjectives substitute cantik and elok. (1) Dengan penghijauan di kawasan pesisir ini juga akan menjaga pantai agar cantik dan bebas dari abrasi. With the greening of coastal areas will also keep the beach so beautiful and free from abrasion. (2) Dengan penghijauan di kawasan pesisir ini juga akan menjaga pantai agar indah dan bebas dari abrasi. With the greening of coastal areas will also keep the beach so beautiful and free from abrasion.

Adjectives cantik and elok can be interchanged in the same sentence context and meaning context of the sentence unchanged. Sentence (2) and sentence (3) has the same structure and the same meaning. After testing the analysis of components of meaning, the same antonyms, and substitutions can be declared air beautiful and elegant synonymous.

2. Type synonymy synonym pair Indonesian adjectives sensory perception

In this study only found two types of four types of existing synonymy, ie 1 paired of adjectives to the type of complete and absolute synonymy and 59 pairs with synonymy incomplete and not absolute. Synonymy completed and absolute and not complete and absolute synonymy not found. Couple adjective sensory perception which has a kind of complete and absolute synonyms are 
adjectives asri and indah analysis of components of meaning adjectives asri and indah discussed in table 3.

Table 3. Component Analysis Adjective meaning beautiful and picturesque

\begin{tabular}{|c|c|c|c|c|}
\hline \multirow[b]{2}{*}{ No. } & \multirow{2}{*}{\multicolumn{2}{|c|}{ Meaning component }} & \multicolumn{2}{|c|}{ Pair Synonymous } \\
\hline & & & ssri & indah \\
\hline \multirow[t]{2}{*}{1.} & Cogniti- & beautiful and unsightly & + & + \\
\hline & ve & unsightly state & + & + \\
\hline 2. & Emotive & has a delicate flavor value & + & + \\
\hline
\end{tabular}

Adjective asri and indah to have cognitive and emotive meaning the same, namely (+) BEAUTIFUL AND unsightly and (+) VALUE OF FINE TASTE. Although the adjective pairs lush and beautifully full synonymous, but these words are not interchangeable in any context (only certain contexts). (1) *Anda tidak harus menggunakan banyak riasan untuk membuat tampilan mata Anda asri. ${ }^{*}$ You do not have to use a lot of makeup to make your eyes look beautiful.(2) Anda tidak harus menggunakan banyak riasan untuk membuat tampilan mata Anda indah. You do not have to use a lot of makeup to make your eyes look beautiful.

Sentence that is prevalent in the sentence (4) not the sentence (5). In the science of language, the word is synonymous complete is to be found even though only in limited quantities. However, a couple of synonyms can not synonymous absolute.

Type synonymy synonym pairs adjective most commonly found types of synonymy is incomplete and not absolute. This synonymy type found as many as 59 pairs of adjectives. The following is a kind of synonymy incomplete findings and not absolute, ie for couples adjectives lancar and fasih.

Table 4. Analysis of Component Meaning Adjective smooth and fluent

\begin{tabular}{cllcc}
\hline & \multicolumn{1}{c}{ Component Meaning } & \multicolumn{2}{c}{ Pair Synonymous } \\
No. & & Lancar & fasih \\
1. & Cognitive & no-hook snagged & + & - \\
& unbroken & + & + \\
& is not halting & + & - \\
& is not delayed & + & - \\
& progressing well & + & + \\
& nice and clean pronunciation & + & + \\
& of the language & + & + \\
\hline
\end{tabular}

Based on table 4, it is understood that the adjectives lancar have more general meaning than fasih.The significance of component analysis, special significance adjective lancar is the $(+)$ UNDERWAY WITH GOOD and special meaning adjective fasih is (+) GOOD AND CLEAN pronunciation. Adjectives lancar and fasi, not interchangeable in any context as in the following sentence. (1) Pelatih Persipura menilai skema permainan timnya berjalan lancar. Coach Persipura assesses his game scheme runs smoothly.(2) *Pelatih Persipura menilai skema permainan timnya berjalan fasih. ${ }^{*}$ Coach Persipura assess his team's running game scheme fluent.

Nuance of meaning is synonymous sensory response Indonesian adjectives

In analysis 60 adjective pairs synonym sensation, only one pair of which do not have shades of meaning for the couple is complete synonyms. There are 59 pairs sensory perception is synonymous adjectives have the nuance of meaning (difference of meaning thin).

Not all pairs of words that are considered synonymous or have the same meaning proven 
synonymous. Nothing really synonymous word pairs is complete and absolute. The research result supports previous research Edmonds and Hirst, 2002 stated that no word is synonymous complete and absolute. Although there are, it is very near synonym actually still has a different meaning, although the difference is only in nuance of meaning.

Bloomfield cites the opinion, in the science of language has become axioms (statements which can be accepted as true without proof) that a thorough synonymy never existed. Therefore, there are no words that really synonymous.) (Wijana \& Rohmadi 2008, p. 29). Absolute synonymy was never found. Although the words are synonyms have the same meaning, but the meaning is not comprehensive (total). This is in accordance with the opinion of Cruse (2000) says that"natural languages sbhor absolute synonyms just as nature abhors a vacuum". The statement was made because the meaning of words continues changing. Synonyms close it actually still has a different meaning, although the difference is only in shades of meaning (Edmonds and Hirst, 2002, p. 115). Veerhar (1999) states, although a couple of synonyms have nearly the same meaning, the word pairs have different shades (Pateda, 2010). If there are no shades of difference again between pairs of words are synonyms, then one will be missing from the vocabulary, and said the other live. Thus, even though the words are synonyms have the same meaning, that meaning is not entirely the same. Thus, different phonemic word, its meaning is different although the differences were similar nuance.

\section{Conclusions}

Based on the analysis that has been done about the nuances of meaning is synonymous adjectives Indonesian sensory feedback, we can conclude the following three conclusions. First, not all sensory responses Indonesian adjectives have a couple of synonyms. Of the 80 pairs of adjectives sensory feedback bersinoim suspected Indonesian, only 60 pairs were proved synonymous. Testing is done with a test synonymous component analysis of meaning, antonyms, and substitute. Not all synonyms have the same antonyms. Of the three test synonymous, there is only two of the most influential test determine synonymy pairs of words, the meaning of test components and test sustitute. Second, only found two types of synonymy in pairs synonymous adjectives sensation, ie, complete and absolute, and incomplete and not absolute. Third, no pair of words that are actually synonymous or has exactly the same meaning, but the word pairs have the nuanced differences. Couple adjective that does not have the feel that meaning is synonymous adjectives pair complete. The results could have implications for learning Indonesian, the language of scientific research and development and user community appears logical language. This research can berimpllikasi in learning in elementary, junior high, high schools, and universities, especially in learning Indonesian vocabulary, composition, writing, and speaking carefully. This study developed micro linguistic studies, especially studies on the assessment synonymous lexical semantics. For further research, this research can be a support for relevant research. For Indonesian users, this research can increase knowledge and mastery of the vocabulary of Indonesian users. Paying attention to nuances of meaning pairs of synonyms can help language users see the relationship between the words the same meaning to make a sharper distinction and appropriate.

\section{Acknowledgments}

During the making of this journal, the authors got a lot of feedback and guidance from the counselors. Therefore, the authors would like to thank Dr. Ngusman Abdul Manaf, M. Hum. as a mentor I and Dr. Novia Juita, Hum. as a mentor II patiently and willingly have given their time, input and guidance to the author in completing this research journals. 


\section{Reference}

Alwi, H., Dardjowidjojo, S., Lapoliwa, H. \& Moeliono, A. M. (2003). Tata bahasa baku bahasa Indonesia. Jakarta: Balai Pustaka.

Carapic, D. (2014). Units of synonymy and lexical relations. Linguistics and Literature, 12 (1), $11-24$.

Cruse, DA (2000). Meaning in language: an introduction to semantics and pragmatics. Cambridge: Cambridge University Press.

Danglli, L. (2014). Units of synonymy and lexical relations. Mediterranean Journal of Social Sciences, 5 (13), 521-525.

Danglli, L. \& Abazaj, G. (2014). Lexical cohesion, word choice and synonymy in academic writing. Mediterranean Journal of Social Sciences, 5 (14), 628-632.

Edmonds, P \& Hirst, G. (2002) Near synonymy and lexical choice. Computational Linguistics, 28 (2), $105-144$.

Ekoyanantiasih, R. \& Winarti, S. (2010) Tata hubungan makna kesinoniman dalam nomina insani Indonesia. Jakarta: Kemendiknas.

Gina, B. (2015). Componential analysis and lexical field structure that berkomponen Indonesian verb meaning (+ action + head + man + partners + deliberately * targeted). Nuance Indonesia, XVII (1), $11-12$.

Hardaniwati, M. 2009. Medan makna sikap dan gerak tubuh dalam bahasa Indonesia: suatu analisis semantik. (Tesis, Universitas Negeri Jakarta, 2009).

Junianto. (2015). Nuansa makna verba aktivitas tangan dalam bahasa Indonesia. (Tesis, Universitas Negeri Padang, 2015)

Pateda, M. (2010). Semantik leksikal. Jakarta: Rineka Cipta.

Payne, J., Huddleston, R., \& Pullum, GK (2010). The distribution and status category of adjectives and adverbs, Word Structure,3 (1), 31-81.

Ekoyanantiasih, R. \& Winarti, S. (2010) Tata hubungan makna kesinoniman dalam nomina insani Indonesia. Jakarta: Kemendiknas.

Rahmati, F. (2015). Semantic shift, homonyms, synonyms and autoantonyms, WALIA 31(S3), 81-85

Shiyab, S. M. (2007). Synonym in translation. Translation Studies Department United Arab Emirates University, UAE, 11 (4).

Tanjung, N. S. (2013). Penggunaan adjektiva dan adverbia dalam novel rebet dan padanannya dalam bahasa Indonesia karya Martin Jankowski. (Skripsi, Universitas Negeri Yogyakarta, 2013).

Taylor, JR (2002). Near synonyms as co-extensive categories: 'high' and 'tall' revisited, Language Sciences,25, 263-284.

Umiyati, M. (2015). Prototipe semantis adjektiva bahasa Indonesia: kendala dan keunikannya. Jurnal Ilmu Bahasa, 1(1), 61-80. DOI: 10.22225/jr.1.1.109. 61-80.

Utami, R. (2010). Kajian sinonim nomina dalam bahasa Indonesia. (Tesis, Universitas Sebelas Maret)

Verhaar, J.W.M. (1999). Asas-asas linguistik umum. Yogyakarta: Gadjah Mada.

Wahyuningsih, A. (2013). Synonymy human noun in Malay dialect Sambas. (Thesis, University Tanjongpura, 2013).

Webb, S. (2007). The effects of synonymy on second language learning vocabulary. Reading in a Foreign Language, 19 (2), 121-122.

Wijana, I. D. P \& Rohmadi, M. (2008). Semantik: teori dan analisis. Surakarta: Yuma Pustaka.

Zapata, AA (2008). Semantics relationship. Ingles, IV, 1-6. 